\title{
PENGEMBANGAN MODUL MATA KULIAH \\ BAHASA INDONESIA MENGGUNAKAN MODEL ADDIE \\ BAGI MAHASISWA IAI SUNAN KALIJOGO MALANG
}

\author{
Gatut Setiadi1), Nurma Yuwita2) \\ 1)IAI Sunan Kalijogo Malang, Universitas Yudharta2) \\ 1)gatutsetiadi@iaiskjmalang.ac.id, nurma@yudharta.ac.id
}

\begin{abstract}
Abstrak: Modul menjadi salah satu sarana untuk membantu mahasiswa dalam menguasai materi perkuliahan kuliah, maka itu pelaksanaan penelitian pengembangan modul untuk mata kuliah Bahasa Indonesia ini memiliki tujuan agar dapat mendeskripsikan: (1) desain pengembangan modul bahasa Indonesia, dan (2) hasil nilai kelayakan dan efektifitas produk modul Bahasa Indonesia yang dapat digunakan dalam perkuliahan. Pengembangan modul ini menggunakan model pengembangan ADDIE yang diterapkan untuk membuat produk modul tersebut. Metode pengumpulan data yang digunakan adalah kuesioner dan angket tertutup. Analisis data menggunakan teknik analisis deksriptif kualitatif dan deskriptif kuantitatif. Berdasarkan hasil penelitian diketahui bahwa modul Bahasa Indonesia yang dikembangkan dengan menerapka model ADDIE yang meliputi lima tahap, yaitu: (1) analisis (analyze), (2) perancangan (design), (3) pengembangan (development),(4) implementasi (implementation), dan (5) evaluasi (evaluation) sebagai acuan untuk pengembangan modul Bahasa Indonesia memiliki hasil yang menunjukkan bahwa: (1) validasi ahli isi (materi) menilai buku ajar berkualitas baik, (2) validasi ahli desain pembelajaran menilai bawa modul memliki kualitas baik, dan (3) ahli modul pembelajaran menilai modul berkualitas sangat baik. Secara keseluruhan terdapat beberapa saran yang diberikan oleh para ahli yang digunakan untuk perbaikan modul Bahasa Indonesia. Rerata hasil validasi oleh para mahasiswa terhadap produk modul Bahasa Indonesia, mayoritas memberikan nilai modul memiliki kualitas baik.
\end{abstract}

\section{Kata kunci: Modul, Bahasa Indonesia, Model ADDIE}

Abstract: The module is one of the means to assist students in mastering lecture material, so the implementation of module development research for Indonesian language courses has the aim of describing: (1) the design of the Indonesian language module development, and (2) the results of the feasibility and effectiveness scores Indonesian language module products that can be used in lectures. The development of this module uses the ADDIE development model that is applied to make the module product. The data collection methods used were questionnaires and closed questionnaires. The data analysis used qualitative descriptive analysis techniques and quantitative descriptive analysis. Based on the results of the research, it is known that the Indonesian language module developed by applying the ADDIE model includes five stages, namely: (1) analysis (analyze), (2) 
design, (3) development, (4) implementation ( implementation), and (5) evaluation as a reference for developing Indonesian language modules have results that show that: (1) validation of content experts assesses textbooks of good quality, (2) validation of learning design experts assesses that the module has good quality, and (3) the learning module expert rated the module as very good quality. Overall, there are some suggestions given by experts that are used to improve the Indonesian language module. The average results of the validation by the students on Indonesian language module products, the majority gave the module value to have good quality.

\section{Keywords: Module, Indonesian Language, ADDIE Model}

\section{PENDAHULUAN}

Mata kuliah Bahasa Indonesia menjadi mata kuliah umum di perguruan tinggi. Hal ini menandakan pentingnya Bahasa Indonesia untuk dipahami oleh kalangan mahasiswa khususnya di IAI Sunan Kalijogo Malang, bukan hanya sebagai penambah wawasan pengetahuan, namun juga untuk memahami identitas bahasa indonesia melalui bahasa nasional. Namun di perguruan tinggi masih banyak mahasiswa belum begitu memahami tentang Bahasa Indonesia, mulai dari sejarah, kedudukan, fungsi, dan bentuk penulisan karya ilmiah yang sesuai kaidah bahasa indonesia.

Berdasarkan hasil karya ilmiah yang telah dibuat oleh mahasiswa IAI Sunan Kalijogo Malang diketahui bahwa kemampuan mahasiswa dalam memahami bahasa indonesia kurang baik terutama pada bidang penulisan karya ilmiah. Hal tersebut diakibatkan oleh beberapa faktor. 1) pemahaman tentang materi perkuliahan pada mata kuliah Bahasa Inndonesia yang dianggap mudah, 2) buku-buku tentang mata kuliah umum Bahasa Indonesia yang sangat sedikit dimiliki oleh mahasiswa, 3) tingkat baca mahasiswa dan pemahaman tentang bahasa indonesia yang masih kurang baik, 4) mahasiswa lebih mengacu pada sumber yang kurang akurat tingkat kebenarannya yang didapat secara acak dari internet. Hal ini menyebabkan perlunya pengulangan beberapa materi bahasa indonesia yang dulu pernah diajarkan pada tingkat SMA/SMK, dan juga sebuah modul sebagai acuan dalam perkuliahan untuk digunakan oleh mahasiswa di IAI Sunan Kalijogo Malang. Tetapi perbedaan yang terpenting yakni pada tingkat perkuliahan akan lebih ditekankan pada bentuk praktek dan hasil produk bahasa tulis 
ataupun lisan dalam bentuk presentasi hasil. Maka itu untuk menyelesaikan permasalahan tersebut dilakukan suatu penelitian pengembangan yang dapat menghasilkan modul ajar bagi perguruan tinggi yang dapat digunakan baik oleh dosen maupun mahasiswa serta masyarakat yang membutuhkannya. Pengertian penelitian pengembangan menurut Borg \& Gall (dalam Sugiyono) adalah suatu proses yang dipakai untuk mengembangkan dan memvalidasi produk pendidikan. ${ }^{1}$ Sedangkan menurut Seels \& Richey (dalam Setyosari) penelitian pengembangan adaah kajian secara sistematis untuk merancang, mengembangkan dan mengevaluasi programprogram, proses dan hasil-hasil pembelajaran yang harus memenuhi kriteria konsistensi dan keefektifan internal. ${ }^{2}$ Jadi Penelitian pengembangan adalah upaya untuk menghasilkan suatu produk berupa materi, modul, alat dan atau strategi pembelajaran yang digunakan untuk mengatasi pembelajaran di kelas/laboratorium, dan bukan untuk menguji teori. Melalui penelitian pengembangan ini akan dibuat sebuah produk yakni berbentuk modul ajar Bahasa Indonesia yang dapat digunakan untuk tingkat perguruan tinggi. Modul ini dikembangkan dengan berbasis konteks pada mata kuliah Bahasa Indonesia. Modul berbasis konteks menekankan pada hasil pembelajarannya, yakni berupa kompetensi mahasiswa untuk melakukan (doing something) sesuai dengan kompetensi yang diharapkan. Artinya, mahasiwa mampu mengonstruksikan pengetahuan dengan pengalaman yang mereka miliki, dan membelajarkan konsep-konsep, serta bagaimana konsep-konsep tersebut diterapkan dalam hal yang konkret dalam perkuliahan, sehingga mahasiswa dapat bertanggung jawab penuh atas kemampuan belajarnya secara individual. Maka itu agar dapat menghasilkan produk yang sesuai dan efektif, maka model pengembangan yang digunakan yakni model ADDIE yang meliputi lima tahap, yaitu: (1) analisis (analyze), (2) perancangan (design), (3) pengembangan (development),(4) implementasi (implementation), dan (5) evaluasi (evaluation).

\footnotetext{
${ }^{1}$ Sugiyono, Metode Penelitian Pendidikan Pendekatan Keuantitatif, Kualitatif, dan R\&D (Bandung: Alfabeta, 2010) hlm. 407

2 Punaji Setyosari, Metode Penelitian Pendidikan dan Pengembangan, (Jakarta: Kencana, 2016), hlm.
} 194 
Berdasarkan latar belakang yang telah diuraikan, maka rumusan masalah dalam penelitian ini yaitu: (1) Bagaimana pengembangan modul ajar mata kuliah bahasa indonesia denganmenggunakan model ADDIE? (2) Bagaimana hasil efektifitas modul ajar mata kuliah bahasa indonesia menggunakan model ADDIE pada mahasiswa IAI Sunan Kalijogo Malang?

\section{METODE PENELITIAN}

\section{A. Model Pengembangan}

Model pengembangan yang digunakan dalam pengembangan modul mata kuliah Bahasa Indonesia ini adalah Model ADDIE yang merupakan salah satu model penelitian pengembangan. Hal ini sesuai dengan pendapat Ching Yee Yong yang menekankan bahwa model ADDIE adalah proses tradisional seorang pengembang yang bersifat umum dalam merancang pengajaran dan latihan. ${ }^{3} \mathrm{Hal}$ ini sejalan dengan pendapat Sezer bahwa merupakan sistem pendekatan secara tidak langsung, yakni analisis bagaimana hubungan komponen yang satu dengan komponen yang lain dan saling koordinasi, terdiri atas perancangan (design), pengembangan (development), pelaksanaan (implementation), dan penilaian (evaluation). ${ }^{4}$ Selanjutnya, Amri mengemukakan bahwa "model ADDIE dapat diklasifikasikan menjadi lima tahap pengembangan, yakni (1) analysis, (2) design, (3) development, (4) implementation, dan (5) evaluation."5 Pertama, tahap analysis yang dilakukan secara berkala, hal ini dilakukan sebab peneliti sebagai pengembang perangkat pembelajaran. Ada tiga aspek yang harus dianalisis, yakni meliputi analisis 1) mahasiswa, 2) perkuliahan, dan 3) modul untuk menyampaikan bahan ajarnya. Tahap kedua, tahap desain merupakan analog dengan pembuatan RPS . Dalam analog RPS dimuat berbagai informasi kontak, terdiri atas tujuan-tujuan pembelajaran, persyaratan kehadiran, kebijakan keterlembatan pekerjaan, jadwal

\footnotetext{
${ }^{3}$ Ching Yee Yong dkk. 2012 Gender As Moderator Between Level of MATLAB Features Understanding of Education and Learning (online), Vol. 1 No.2

${ }^{4}$ Baris Sezer. 2013. "Integrating Technology Ito Classroom:The Learner-Centered Instructional Design" dalam International Jurnal on New Trend in Educationin Their Implication. Vol.4 No.4 (Online).

${ }^{5}$ Sofan Amri. Pengembangan dan Model Pembelajaran dalam Kurikulum 2013. (Jakarta: Prestasi Pustaka, 2013), hlm. 264
} 
pembelajaran, pengarahan, alat bantu komunikasi, kebijakan teknologi, materi perkuliahan dan desain antar muka untuk pembelajaran. Ketiga, tahap development, yaitu tahap produksi, segala sesuatu yang telah dibuat dalam tahapan desain dan diwujudkan dalam hasil yang nyata. Keempat, tahap Implementation, yaitu pelaksanaan uji coba modul ajar mata kuliah bahasa indonesia yang telah siap untuk digunakan oleh mahasiswa. Kelima, tahap evaluation yakni tahap untuk mengetahui segala kekurangan yang terdapat pada modul tersebut untuk selanjutnya dilakukan revisi agar menghasilkan produk yang tepat dan efektif. Secara visual tahapan ADDIE Model dapat dilihat pada Gambar 1 berikut:

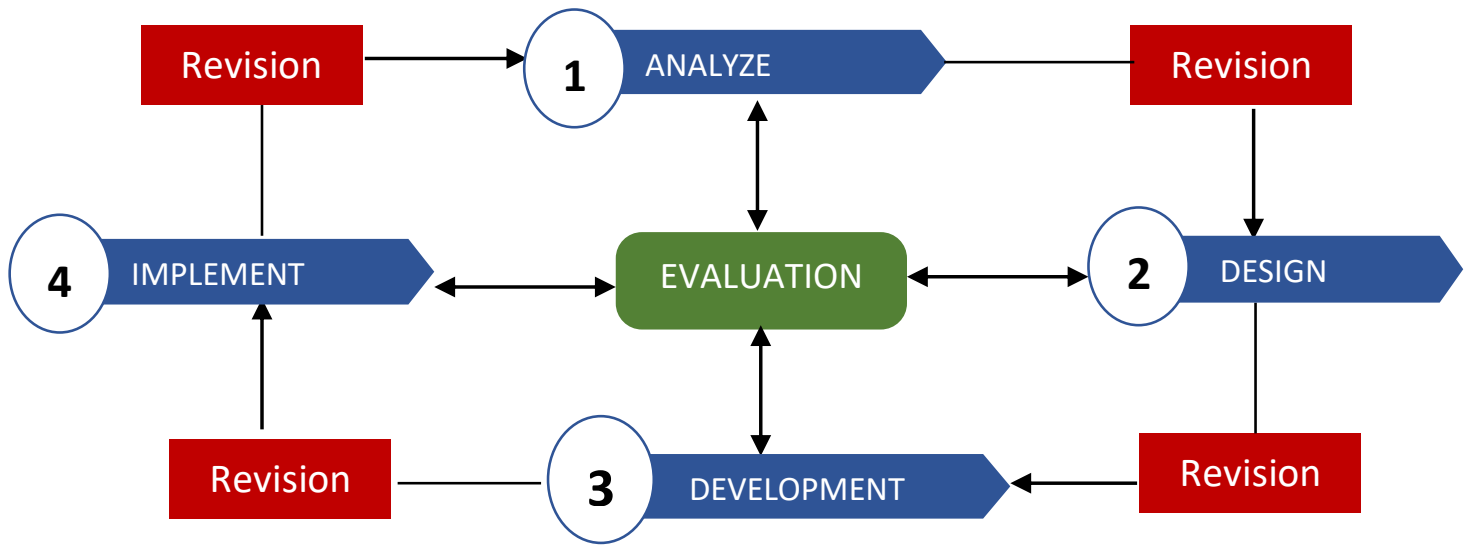

Gambar 1

Bagan Model ADDIE

\section{B. Data Pengembangan}

Data dalam penelitian pengembangan modul pembelajaran interaktif ini adalah (1) berbagai informasi yang berkaitan dengan kebutuhan mahasiswa dan dosen terhadap modul pembelajaran mata kuliah Bahasa Indonesia, dan (2) data yang berkaitan dengan penilaian oleh para ahli dan pengguna terhadap modul mata kuliah Bahasa Indonesia pada tingkat perguruan tinggi.

\section{Sumber Data}

Sumber data merupakan hal yang wajib diperoleh dalam penelitian, karena melalui sumber data yang tepat maka penelitian akan berhasil dengan baik. Moeleong berpendapat bahwa "kata-kata dan tindakan orang-orang yang diamati atau 
diwawancarai merupakan sumber data utama."6 Jadi berdasarkan pendapat tersebut maka yang menjadi sumber data untuk pengembangan modul mata kuliah Bahasa Indonesia ini adalah mahasiswa dan dosen pengampu mata kuliah.

\section{(1) Jenis Data}

Jenis data dalam penelitian pengembangan modul mata kuliah Bahasa Indonesia adalah sebagai berikut:

a) Data Kebutuhan Modul Pembelajaran Mata kuliah Bahasa Indonesia

b) Data Penilaian Modul Pembelajaran Mata kuliah Bahasa Indonesia

\section{(2) Teknik Pengumpulan Data}

Riduwan mendefinisikan bahwa "metode pengumpulan data ialah teknik atau cara-cara yang dapat digunakan oleh peneliti untuk mengumpulkan data."7 Berdasarkan pendapat tersebut, teknik pengumpulan data yang dilakukan oleh peneliti adalah dengan melakukan observasi dan angket.

\section{(3) Instrumen Pengumpulan Data}

Instrumen pengumpulan data terdiri dari 1) lembar observasi, 2) lembar validasi dari ahli materi dan ahli modul. Lembar observasi digunakan untuk mengetahui sarana di sekolah, proses pembelajaran, dan karakteristik mahasiswa di IAI Sunan Kalijogo Malang. Lembar validasi ahli materi digunakan untuk mengetahui tingkat kesesuaian dan ketepatan materi dalam modul dan relevansinya terhadap kompetensi yang diharapkan kepada mahasiswa. Sedangkan lembar validasi ahli media berfungsi untuk mengetahui kelayakan serta kualitas modul pembelajaran interaktif tersebut untuk digunakan dalam pembelajaran di perkuliahan Bahasa Indonesia.

\section{(4) Teknik Analisis Data}

Teknik analisis data dilakukan untuk menganalisa berbagai data yang diperoleh dari berbagai sumber.

Analisis data adalah proses mencari dan menyusun secara sistematis data yang diperoleh dari hasil wawancara, catatan lapangan, dan dokumentasi, dengan cara

${ }^{6}$ Moelong, Lexy J. 2014. Metode Penelitian Kualitatif. (Bandung: PT Remaja Rosdakarya, 2014), hlm. 345

${ }^{7}$ Riduwan. 2013. Metode Penelitian Kombinasi. (cetakan ke-9). (Bandung. Alfabeta, 2013), hlm. 233 
mengorganisasikan data ke dalam kategori, menjabarkan ke dalam unit-unit, melakukan sintesa, menyusun ke dalam pola, memilih mana yang penting dan yang akan dipelajari, dan memuat kesimpulan sehingga mudah dipahami oleh diri sendiri maupun orang lain. ${ }^{8}$

Dalam pengembangan modul mata kuliah Bahasa Indonesia menggunakan teknik analisis data yaitu:

(1) analisis data kualitatif menggunakan analisis model Miles \& Huberman yang melalui tahapan (a) Reduksi, (b) Penyajian data, dan (c) Verifikasi.

(2) Analisis Kuantitatif.

Analisis kuantitatif juga dibutuhkan dalam penelitian ini, karena data yang diperoleh juga membutuhkan suatu sistem perhitungan yang akurat. Analisis data yang digunakan adalah analisis statistik deskriptif. Termasuk dalam statistik deskriptif antara lain adalah penyajian data melalui tabel, grafik, diagram lingkaran, pictogram, perhitungan modus, moduln, mean (pengukuran tendensi sentral), perhitungan desil, presentil, perhitungan penyebaran data melalui perhitungan rata-rata dan standar deviasi. ${ }^{9}$ Dari berbagai bentuk penyajian analisis data deskriptif tersebut, akan dipilih bentuk analisis statistik deskriptif yang sesuai untuk penelitian ini, yakni penyajian data statistik melalui tabel, diagram lingkaran, perhitungan modus, moduln, mean, perhitungan rata-rata dan persentase.

\section{PEMBAHASAN DAN HASIL PENELITIAN}

\section{A. Institut Agama Islam Sunan Kalijogo Malang}

Institut Agama Islam (IAI) Sunan Kalijogo Malang merupakan sebuah perguruan tinggi yang berada di bawah naungan pondok pesantern Sunan Kalijogo Jabung yang diasuh oleh Kiai Muzaki Nur, beliau sebagai penerus tunggal pendiri pondok pesantren tersebut yakni Kiai Nur Salim. IAI Sunan Kalijogo ini terletak di jakan Keramat Desa Sukolilo, Kec. Jabung-Kab. Malang. Perguruan tinggi ini mulai aktif sejak 2018 dan

\footnotetext{
8 Sugiyono. 2016. Metode dan Teknik Menyusun Tesis. (cetakan ke-8). (Bandung. Alfabeta, 2016), hlm. 355.

${ }^{9}$ Ibid hlm.200
} 
memiliki 6 program studi yang dapat dipilih oleh calon mahasiswa yakni 1) Ekonomi Syariah, 2) Perbankan Syariah, 3) Bimbingan Konseling Islam, 4) Manajemen Pendidikan Islam, 5) Pendidikan Bahasa Arab, dan 6) Komunikasi dan Penyiaran Islam.

\section{B. Bahan Ajar berbentuk Modul}

\section{1) Pengertian Bahan Ajar}

Bahan ajar dalam penelitian ini berupa sebuah produk. "Bahan ajar adalah segala bentuk bahan yang digunakan untuk membantu dosen/instruktor dalam melaksanakan kegiatan belajar mengajar.10 Bahan yang dimaksud bisa berupa bahan yang tertulis maupun tak tertulis. Pendapat lain mengatakan bahwa "bahan ajar merupakan segala bahan (baik informasi, alat, maupun teks) yang disusun secara sistematis, yang menampilkan sosok utuh dari kompetensi yang akan dikuasai mahasiswa dan digunakan dalam proses pembelajaran dengan tujuan untuk perencanaan dan penelaahan implementasi pembelajaran. ${ }^{11}$ Bahan ajar yang baik akan memudahkan siswa dalam mempelajari materi secara runtut sehingga siswa dapat menguasai materi dengan baik. Ada enam komponen yang perlu kita ketahui berkaitan dengan unsurunsur bahan ajar, yakni sebagai berikut: 12

(1) Petunjuk belajar

Komponen pertama ini meliputi petunjuk bagi pendidik maupun mahasiswa. Di dalamnya dijelaskan tentang bagaimana pendidik sebaiknya mengajarkan materi kepada mahasiswa dan bagaimana pula mahasiswa sebaiknya mempelajari materi yang ada dalam bahan ajar.

(2) Kompetensi yang akan dicapai

Maksud komponen kedua ini adalah kompetensi yang akan dicapai oleh siswa. Sebagai pendidik harus menjelaskan dan mencantumkan dalam bahan ajara yang disusun tersebut dengan standar kompetensi, kompetensi dasar maupun indikator pencapaian hasil belajar yang harus dikuasai mahasiswa.

\footnotetext{
${ }^{10}$ Abdul Majid. Perencanaan Pembelajaran,(Bandung: PT. Remaja Rosdakarya,2007), hlm. 173.

${ }^{11}$ Andi Prawoto, Panduan Kreatif Membuat Bahan ajar Inovatif, (Jogjakarta: DIVA Press, 2012), hlm. 16

12 Ibid. hlm. 28-30
} 
(3) Informasi pendukung

Informasi pendukung merupakan bagian informasi tambahan yang dapat melengkapi bahan ajar, sehingga mahasiswa akan semakin mudah untuk menguasai pengetahuan yang akan diperoleh.

(4) Latihan-latihan

Komponen ke empat ini merupakan suatu bentuk tugas yang diberikan kepada mahasiswa untuk melatih kemampuan mereka setelah mempelajari bahan ajar.

(5) Evaluasi

Dalam komponen evaluasi terdapat sejumlah pertanyaan yang ditujukan kepada mahasiswa untuk mengukur seberapa jauh penguasaan kompetensi yang berhasil mereka kuasai setelah mengikuti proses pembelajaran.

\section{2) Fungsi modul}

Sebagai salah satu bentuk bahan ajar, modul memiliki fungsi sebagai berikut:13

(1) Bahan ajar mandiri.

Penggunaan modul dalam proses pembelajaran berfungsi meningkatkan kemampuan mahasiswa, karena modul bersifat metakognitif untuk belajar sendiri tanpa tergantung kepada kehadiran pendidik.

(2) Pengganti fungsi pendidik.

Modul sebagai bahan ajar yang harus mampu menjelaskan materi pembelajaran dengan baik dan mudah dipahami oleh mahasiswa sesuai tingkat pengetahuan dan usia mereka. Maka dari itu, penggunaan modul bisa berfungsi sebagai pengganti fungsi atau peran fasilitator/ pendidik.

(3) Sebagai alat evaluasi.

Penggunaan modul menuntut mahasiswa untuk dapat mengukur dan menilai sendiri tingkat penguasaan terhadap materi yang telah dipelajari.

(4) Sebagai bahan rujukan bagi mahasiswa.

\footnotetext{
${ }^{13}$ Andi Prawoto, Panduan Kreatif Membuat Bahan ajar Inovatif, (Jogjakarta: DIVA Press, 2012), hlm. 29.
} 
Modul mengandung berbagai materi yang harus dipelajari oleh mahasiswa, maka modul juga dapat digunakan mahasiswa sebagai referensi untuk menulis karya ilmiah.

\section{Langkah-langkah Pengembangan Modul menggunakan model ADDIE}

Dalam penyusunan sebuah modul, ada empat tahapan yang mesti dilalui yaitu analisis kurikulum, penentuan judul modul, pemberian kode modul dan penulisan modul. ${ }^{14}$

\section{Analisis (analyze)}

a) Analisis Kurikulum

Tahap ini bertujuan untuk menentukan kesesuaian materi perkuliahan, kegiatan ini dilakukan dengan menganalisis silabus mata kuliah bahasa indonesia yang terdiri dari 14 materi perkuliahan. Berdasarkan analisis yang telah dilakukan maka diketahui daftar materi yang akan dijadikan acuan untuk modul perkuliahan Bahasa Indonesia yaitu: 1) Mengidentifikasi pentingnya mata kuliah bahasa indonesia, 2) memahami sejarah perkembangan bahasa indonesia, 3) memahami ragam bahasa ilmiah, 4) kata dan perubahan makna, 5) frasa, kalusa, kalimat, 6) kalimat, unsur kalimat, dan jenis kalimat, 7) paragraf dalam teks, 8) unsur pembentuk paragraf, 9) penyusunan karangan, 10) kutipan, sistem rujukan, dan daftar pustaka, 11) karya ilmiah, 12) langkah menulis karya ilmiah, 13) mnyunting naskah karya ilmiah, 14) presentasi ilmiah.

b) Analisis Kebutuhan dan Permasalahan Mahasiswa

Analisis ini dilakukan dengan mengidentifikasi permasalahan mahasswa dan mahasiswa di IAI Sunan Kalijogo Malang. Berdasarkan hasil analisis kebutuhan dan permasalahan maka dapat dideskripsikan sebagai berikut. 1) mahasiswa sangat membutuhkan modul bahasa indonesia sebagai referensi yang mampu meningkatkan kemampuan mahasiswa tentang bahasa indonesia di tingkat perguruan tinggi, 2) Mahasiswa membutuhkan produk berupa modul yang sesuai dengan karakteristik mahasiswa di IAI Sunan Kalijogo Malang yang berbasis pondok pesantren, 3) mahasiswa

${ }^{14}$ Ibid hlm.118 - 131 
masih mengandalkan sumber belajar dari internet yang tingkat kebenaran materinya kurang akurat, sedangkan yang mahasiswa santri tidak memiliki referensi yang sesuai dan tepat, oleh sebab itu, perlu adanya dikembangkan sebuah modul mata kuliah bahasa indonesia.

\section{Perancangan (Design)}

Tahap perancangan modul Bahasa Indonesia dapat dideskripsikan menjadi beberapa langkah yaitu:

a) Rancangan Modul

Modul dirancang dengan menggunakan model belajar metakognitif yang terdiri: Pertama, komponen konstruktivisme, komponen dalam modul dapat berupa materi sebagai pemahaman awal mahasiswa, untuk membangun pemahaman awal mahasiswa tentang mata kuliah Bahasa Indonesia di perguruan tinggi. Kedua, komponen inkuiri dalam modul dapat berbentuk menemukan sesuatu dengan penalaran mahasiswa terhadap materi yang dipelajari. Mahasiswa diberikan kebebasan untuk menemukan konsep sendiri berdasarkan kemampuan serta daya nalar mahasiswa terhadap materi perkuliahan yang sedang dipelajari. Ketiga, komponen komunikatif, dalam modul dapat berbentuk latihan bagi mahasiswa untuk memecahkan masalah dalam kehidupan. Hal ini dapat menumbuhkan sikap kritis mahasiswa untuk memecahkan masalah dengan baik. Keempat komponen penilain autentik, penilain dalam modul ini dilakukan melalui penampilan (performance) mahasiswa ketika presentasi hasil kerja dan selama proses perkuliahan. Penilaian diterapkan dengan tes sumatif dan tes formatif.

b) Anatomi Modul

Pengembangan modul bahasa indonesia ini memiliki anatomi yang terdiri dari: Pertama, sampul modul yang dirancang memuat identitas, yaitu judul modul, mata kuliah, nama perguruan tinggi, dan identitas penulis modul, seperti tampak pada gambar 2 berikut: 


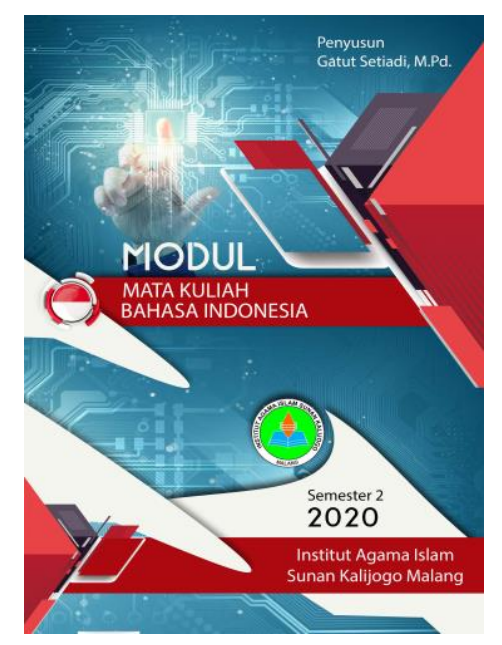

Gambar 2

Cover Modul Mata Kuliah Bahasa Indonesia

Kedua, kata pengantar modul merupakan landasan filosofis analisis, perencanaan, pengembangan, pelaksanaan, dan evaluasi.

Ketiga, Petunjuk bagi Mahasiswa berisi tentang instruksi yang berpedoman pada Standar Kompetensi (SK), Kompetensi Dasar (KD), indikator pembelajaran, tujuan pembelajaran.

Keempat, daftar isi dalam modul merupakan uraian pokok bahasan dalam modul yang bertujuan untuk memudahkan pembaca mengetahui isi modul yang dibuat.

Kelima, komponen kegiatan belajar modul (materi perkuliahan), modul disesuaikan dengan SK, KD, indikator pembelajaran, dan tujuan pembelajaran yang terdapat dalam silabus perkuliahan.

Keenam, lembar kerja mahasiswa, dalam modul berisi beberapa pertayaan terait materi perkuliahan, yang aspek pertanyaan bertujuan untuk mengembangkan kemampuan mahasiswa,

Ketujuh, daftar rujukan, dalam modul bagian ini berisi berbagai referensi atau sumber yang berkaitan dengan materi perkuliahan Bahasa Indonesia.

\section{Tahap Pengembangan (Development)}

(a) Prosedur Pengembangan 
Tahap awal penelitian pengembangan dilakukan dengan pengumpulan berbagai data yang diperlukan, khususnya referensi mengenai materi materi perkuliahan Bahasa Indonesia. Tahap selanjutnya yaitu penyusunan kisi-kisi, serta instrumen penelitian dan pengembangan modul. Tahap akhir dari penelitian ini adalah penilaian. Modul mata kuliah Bahasa Indonesia ini divalidasi oleh ahli materi dan ahli modul. Setelah kemudian modul direvisi sehingga diperoleh modul revisi tahap I. Modul pembelajaran interaktif hasil revisi tahap I kemudian diujicobakan dengan cara digunakan oleh dosen dalam perkuliahan. Modul yang telah melalui proses uji coba akan direvisi kembali tahap II untuk mendapatkan modul yang sesuai dan layak digunakan dalam pembelajaran. Berdasarkan tahap-tahap tersebut, maka akan dihasilkan produk akhir modul mata kuliah Bahasa Indonesia.

\section{Implementasi (implementation)}

Implentasi dalam penelitian ini dilakukan melalui uji coba produk, dengan tujuan agar dapat diketahui tentang keefektifitasan produk pengembangan yang dihasilkan, berikut ini uraian tentang uji coba produk pengembangan modul mata kuliah Bahasa Indonesia di IAI Sunan Kalijogo Malang.

\section{Desain Uji Coba Produk}

Desain uji coba yang dilakukan ada 3 tahapan yaitu:

(2) Uji ahli atau validasi, Uji coba ini dilakukan dengan penggunanya adalah ahli modul dan ahli materi.

(3) Uji coba perseorangan yang ditujukan pada penggunanya yakni dosen mata kuliah Bahasa Indonesia

(4) Uji coba kelompok kecil atau terbatas dengan penggunanya adalah sebagian dari prodi ekonomi syariah.

\section{Subjek Uji Coba}

Subjek uji coba produk modul mata kuliah Bahasa Indonesia ini dilakukan pada konsumen pengguna produk yaitu:

(1) Dosen mata kuliah Bahasa Indonesia berjumlah 1 orang

(2) Mahasiswa prodi ekonomi syariah dari IAI Sunan Kalijogo Malang 
(3) uji coba kelompok kecil dengan pengguna modul pembelajaran interaktif sebanyak 10 mahasiswa yang dipilih dengan tiga kategori nilai prestasi di kelas yaitu: 2 mahasiswa dengan nilai tertinggi, 2 mahasiswa dengan nilai menengah, 6 mahasiswa dengan nilai terendah. Jumlah pengguna mahasiswa nilai terendah lebih banyak karena disesuaikan dengan tujuan pengembangan produk ini, yakni untuk meningkatkan minat dan kemampuan mahasiswa dalam belajar Bahasa Indonesia.

(4) Uji Coba Kelompok Besar

Uji coba kelompok besar dilakukan di Program Studi Ekonomi Syariah IAI Sunan Kalijogo Malang. Subjek uji coba dalam penelitian ini adalah mahasiswa prodi Ekonomi Syariah yang berjumlah 27 orang mahasiswa.

\section{Evaluasi (evaluation)}

\section{A. Hasil Analisis Kebutuhan}

Agar pengembangan modul pembelajaran interaktif ini dapat tepat guna ketika digunakan dalam pembelajaran yang dilaksanakan, maka perlu dilaksanakan dua hal yaitu:

1) Observasi untuk mengetahui sarana dan prasarana yang ada di sekolah.

Dari hasil observasi dipahami tentang

a) jumlah mahasiswa prodi ekonomi syariah yakni, laki-laki berjumlah 14 orang dan perempuan 13 orang, dengan persentase laki-laki 57,78\% dan perempuan 47,22\%, jadi mahasiswa laki-laki 1 orang atau 5,56\% lebih banyak dibandingkan mahasiswa perempuan.

b) IAI Sunan Kalijogo Malang memiliki belum memiliki referensi yang sesuai untuk pembelajaran mata kuliah Bahasa Indonesia.

2) Analisis kebutuhan mahasiswa dan dosen.

Untuk memahami tentang tingkat kebutuhan modul pembelajaran interaktif di IAI Sunan Kalijogo Malang pada prodi ekonomi syariah, maka digunakan angket yang terdiri dari, 
a) Analisis angket kebutuhan mahasiswa, yang mengisi angket ini adalah mahasiswa prodi ekonomi syariah IAI Sunan Kalijogo Malang sebanyak 27 mahasiswa, dengan rincian 14 mahasiswa laki-laki dan 13 mahasiswa perempuan.

b) Analisis angket kebutuhan dosen, untuk angket ini diisi oleh seorang Dosen Bahasa Indonesia dari IAI Sunan Kalijogo Malang, hasil isian angket kebutuhan dosen tersebut yang dijadikan dasar pembuatan modul pembelajaran interaktif.

Data dari angket tersebut dianalisis menggunakan skala Guttman. ${ }^{15}$ Skala Guttman adalah skala yang digunakan untuk jawaban yang bersifat jelas (tegas) dan konsisten. Berdasarkan hasil angket tersebut dapat diambil kesimpulan yaitu, 1) dibutuhkan modul mata kuliah Bahasa Indonesia bagi mahasiswa, 2) mayoritas mahasiswa masih belum memahami tentang struktur, kaidah kebahasaan, dan cara membuat serta menyajikan karya ilmiah, 3) dalam modul pembelajaran mata kuliah Bahasa Indonesia dibutuhkan mahasiswasebagai referensi tambahan yang menjadi acuan untuk perkuliahan Bahasa Indonesia.

B. Penyajian Data Uji Coba

Uji coba ini dilaksanakan pada hari sabtu tanggal 21 Agustus 2018 dengan alokasi waktu 2 jam pelajaran ( 2 x 50 menit). Dari hasil uji coba kelompok kecil tersebut dapat dipahami bahwa modul pembelajaran Bahasa Indonesia telah memperoleh nilai 3,6 jika dikonversi sesuai dengan tabel konversi nilainya menjadi 86, jadi modul tersebut termasuk dalam kategori Baik, tetapi masih perlu sedikit perbaikan.

C. Nilai Validasi Kelayakan

Karena modul ini diperuntukkan dalam suatu pembelajaran, maka hal yang terpenting dalam pengembangan modul pembelajaran interaktif ini adalah nilai kelayakan dari modul tersebut, nilai kelayakan ini diperoleh dari ahli modul yang menguasai tentang TIK dan ahli materi mata pelajaran Bahasa Indonesia. Berikut ini hasil penilaian dari ahli materi dan ahli modul tentang kelayakan modul pembelajaran interaktif tersebut.

\section{a. Nilai Validasi dari Ahli Media}

15 Riduwan. 2013. Metode Penelitian Kombinasi. (cetakan ke-9). Bandung. Alfabeta. 
Dari tahap 1 ke tahap 2 setelah dilakukan perbaikan, maka ada peningkatan nilai 0,9 sehingga nilai yang sebelumnya 3,3 menjadi 3,9. Nilai tersebut jika dikonversi menjadi 89 dan memiliki kategori Baik, jadi karena rata-rata nilai tiap bagian sudah di atas 3 maka modul pembelajaran interaktif telah memperoleh kelayakan yang dibutuhkan untuk suatu modul pembelajaran interaktif.

\section{b. Nilai Validasi dari Ahli Materi}

Berdasarkan dari data penilaian validasi diketahui terdapat kenaikan nilai 0,3 point, sehingga nilai rata-rata yang awalnya 3,1 jika dikonversi menjadi 81 naik menjadi 3,4 yang dikonversi menjadi 84 dan tergolong berkategori Baik. jadi ini berarti materi dalam modul pembelajaran interaktif ini sudah layak untuk digunakan dalam suatu proses pembelajaran.

D. Nilai Kualitas Modul Pembelajaran Mata kuliah Bahasa Indonesia

Modul pembelajaran interaktif ini juga memperoleh nilai kualitas yang diberikan oleh dosen dan mahasiswa prodi ekonomi syariah dari IAI Sunan Kalijogo Malang, karena dosen dan mahasiswa tersebut adalah pengguna dari modul pembelajaran interaktif ini. Berdasarkan nilai dari angket penilaian kualitas yang diberikan oleh dosen modul pembelajaran interaktif mendapatkan nilai $\mathbf{4}$, jadi modul pembelajaran interaktif tersebut mendapatkan pernyataan Sesuai, maka modul pembelajaran ini dapat digunakan dalam pembelajaran mata kuliah Bahasa Indonesia di IAI Sunan Kalijogo Malang. Sedangkan dari hasil perhitungan persentase penilaian kualitas modul oleh mahasiswa, karena mayoritas pernyataan telah mendapat kriteria Sesuai, maka dapat disimpulkan bahwa modul pembelajaran mata kuliah Bahasa Indonesia telah Sesuai untuk digunakan dalam proses perkuliahan. Berikut ini tabel persentase penilaian kualitas modul pembelajaran interaktif dari mahasiswa

\begin{tabular}{|c|c|c|c|c|c|c|c|}
\hline \multirow{2}{*}{ No. } & \multicolumn{3}{|c|}{ Persentase Tiap Pernyataan } & \multirow{2}{*}{$\begin{array}{c}\text { Persentase } \\
\text { Keseluruhan }\end{array}$} & $\begin{array}{c}\text { Kriteria } \\
\text { Interpretasi } \\
\text { Skor }\end{array}$ \\
\hline 1 & SS & S & CS & KS & TS & $77 \%$ & $\mathrm{~S}$ \\
\hline 2 & $14 \%$ & $64 \%$ & $17 \%$ & $6 \%$ & $0 \%$ & $81 \%$ & $\mathrm{SS}$ \\
\hline 3 & $0 \%$ & $36 \%$ & $58 \%$ & $6 \%$ & $0 \%$ & $66 \%$ & $\mathrm{~S}$ \\
\hline 4 & $0 \%$ & $58 \%$ & $33 \%$ & $8 \%$ & $0 \%$ & $70 \%$ & $\mathrm{~S}$ \\
\hline 5 & $53 \%$ & $25 \%$ & $22 \%$ & $0 \%$ & $0 \%$ & $86 \%$ & $\mathrm{SS}$ \\
\hline 6 & $0 \%$ & $44 \%$ & $53 \%$ & $3 \%$ & $0 \%$ & $68 \%$ & $\mathrm{~S}$ \\
\hline
\end{tabular}




\begin{tabular}{|c|c|c|c|c|c|c|c|}
\hline 7 & $0 \%$ & $67 \%$ & $33 \%$ & $0 \%$ & $0 \%$ & $73 \%$ & $\mathrm{~S}$ \\
\hline 8 & $8 \%$ & $53 \%$ & $39 \%$ & $0 \%$ & $0 \%$ & $74 \%$ & $\mathrm{~S}$ \\
\hline 9 & $22 \%$ & $58 \%$ & $19 \%$ & $0 \%$ & $0 \%$ & $81 \%$ & SS \\
\hline 10 & $17 \%$ & $72 \%$ & $11 \%$ & $0 \%$ & $0 \%$ & $81 \%$ & SS \\
\hline
\end{tabular}

\section{Efektivitas Produk Modul Pembelajaran Mata kuliah Bahasa Indonesia}

Untuk memahami tingkat efektivitas modul pembelajaran maka dilakukan dua tes yaitu pretest dan postes. Pretes dilaksanakan pada hari Sabtu tanggal 28 Juli 2018 sedangkan pretes dilaksanakan pada hari Sabtu tanggal 23 Desember 2018. Alokasi waktu yang digunakan yakni masing-masing tes 3 jam pelajaran (120 menit). Dari perbandingan hasil pretes dan postes dapat diketahui hampir tiap mahasiswa mengalami kenaikan nilai antara 5 sampai 20 point atau persentase antara $6 \%$ sampai 30\%. Dari jumlah mahasiswa berjumlah 27 orang, yang memperoleh kenaikan nilai sebanyak 34 mahasiswa, dan nilai rata-rata kelas yang sebelumnya 70,4 naik menjadi 80,4 atau 14\% dan telah melebihi nilai KKM yang telah ditetapkan di sekolah yakni 75 . Berdasarkan persentase tersebut menunjukkan bahwa modul pembelajaran interaktif mampu mengembangkan kemampuan mahasiswa pada mata kuliah Bahasa Indonesia.

\section{KESIMPULAN}

Berdasarkan hasil pengembangan modul berbasis metakognitif dapat disimpulkan sebagai berikut. A) penelitian dan pengembangan modul berbasis metakognitif ini menggunakan model ADDIE yang dilakukan melalui lima tahapan yang terdiri atas (1) analisis, (2) perancangan, (3) pengembangan, (4) pelaksanaan, dan (5) evaluasi. B) pengembangan modul berbasis metakognitif untuk mata kuliah Bhasa Indonesia mendapat kategorikan baik dan sesuai berdasarkan validasi oleh validator ahli (expert judgement). 3), dalam pengembangan modul, revisi dilakukan sesuai dengan masukan, saran, dan penilaian validator ahli dilihat dari aspek isi modul, penyajian modul, kebahasaan modul, dan kegrafikaan modul. 4) modul berbasis metakognitif pada mata kuliah Bahasa Indonesia dapat digolongkan sangat praktis, dilihat dari kemudahan dalam penggunaan modul untuk dosen dan mahasiswa. Materi disajikan dalam modul 
disusun dengan runtut, sistematis, dan jelas disesuaikan dengan urutan pada silabus perkuliahan.

\section{DAFTAR PUSTAKA}

Majid, Abdul. Perencanaan Pendidikan. Bandung: PT Remaja Rosdakarya, 2007.

Moelong J,, Lexy. Metode Penelitian Kualitatif. Bandung: PT Remaja Rosdakarya, 2014.

Prawoto, Andi. Panduan Kreatif Membuat Bahan ajar Inovatif. Yogyakarta: DIVA Press, 2016.

Punaji, Setyosari. Metode Penelitian Pendidikan dan Pengembangan. Jakarta: Kencana, 2016.

Riduwan. Metode Penelitian Kombinasi. Cetakan ke-9. Bandung: Alfabeta, 2015.

Sezer, Baris. "Integrating Technology in To Classroom: The Learning-Centered Instructional Design." International Jurnal on New Trend in Educationin Their Implication. Vol. 4 No. 4 (Online), 2013: 78.

Sofan, Amri. Pengembangan dan Model Pembelajaran dalam Kurikulum 2013. Jakarta: Prestasi Pustaka, 2013.

Sugiyono. Metode dan Teknik Menyusun Tesis. Cetakan ke-8. Bandung: Alfabeta, 2016.

-. Metode Penelitian Pendidikan Pendekatan Keuantitatif, Kualitatif, dan R\&D. Bandung: Alfabeta, 2010. 